\title{
Effect of Weed Management Practices in Rajmash (Phaseolus vulgaris L.)
}

\author{
D. Sekhar*, L. Suryanarayana and K. Tejeswara Rao \\ Regional Agricultural Research Station, Chintapalli - 531111, Andhra Pradesh, India \\ *Corresponding author
}

\section{A B S T R A C T}

A field experiment was conducted during rabi season of 2013-14to 2015-16 on sandy clay loam soil at Regional Agricultural Research Station, Chintapalli, Andhra Pradesh to find

Keywords

Rajmash, Weed control,

Pre and post emergence

herbicides, Yield, Benefit

cost ratio, HAT zone

Article Info

Accepted:

04 August 2018

Available Online:

10 September 2018 out the efficient weed management practices of rajmash crop in high altitude and tribal zone. The experiment consists of twelve treatments involving different chemical combinations. The results indicated that among weed management practices adopted preemergence application of pendimethalin @ $0.75 \mathrm{~kg}$ ai $/ \mathrm{ha}(1.0 \mathrm{lt} / \mathrm{ac})+$ hand weeding at 30 DAS has recorded significantly higher weed control efficiency at 45 DAS and at harvest, yield and yield attributes. This treatment was on a par with the pre-emergence application of pendimethalin @ $0.75 \mathrm{~kg} / \mathrm{ha}(1.0 \mathrm{lt} / \mathrm{ac})+$ post emergence spray of imazythapyr @ $63 \mathrm{~g}$ ai/ha $(250 \mathrm{~m} / \mathrm{ac})$ at $30 \mathrm{DAS}$. Highest benefit cost ratio was recorded with the application of Pendimethalin@0.75 kg/ha. (1 litre/ac) + imazythapyr @63 gm ai/ha 50 ml /ac) as post emergence at $30 \mathrm{DAS}$. Based on the results, either pre emergence application of pendimethalin along with one hand weeding at 30 DAS or pendimethalin@ $0.75 \mathrm{~kg} / \mathrm{ha}$ $(1.0 \mathrm{lt} / \mathrm{ac})$ as pre emergence, followed by post emergence application of imazythapyr @ 63 $\mathrm{g}$ ai/ha $(250 \mathrm{~m} / \mathrm{ac})$ at 30 DAS can control weeds efficiently in rajmash crop and produce higher yield.

\section{Introduction}

In High Altitude and Tribal (HAT) zone of Andhra Pradesh state, among different pulse crops rajmash (Phaseolus vulgaris) being grown largely during rabi seasonas pulse crop as well as green vegetable. The crop extending to newer areas due to its high profit in comparison to other pulse crops. It has high nutritional value containing 20.69 to $25.81 \%$ crude protein, $1.72 \%$ fats, $72.42 \%$ carbohydrates and $5.83 \mathrm{mg}$ of iron. Moreover, it has good amount of ash content, crude fibre and to total sugars. It is rich in amino acids like tryptophan, methionine and some phenolic compounds like tannin and polyphenol oxidase (Singh et al., 2014). The losses in general, due to weed infestation depends on composition of weed flora, extent of infestation and crop canopy, but it has been estimated that weeds alone can reduce the yield to the tune of $20-60 \%$.

To keep the weeds with in the desirable limit, various methods which include physical, mechanical, chemical and biological are in use and among these methods, control of weeds through herbicide use is not only efficient method but it is easily adoptable by farmers (Panotra et al., 2012). 
Farmers producing lower yields due to unpracticed intercultural operations. Farmers not aware of latest chemical methods of weed management in rajmash crop. Farmers of this zone practicing traditional farming operations to grow the crop. In rajmash crop, growth rate during early stage is slow and weeds dominate the crop and thus yields are largely declined due to the weed problem. In rajmash crop farmers generally practicing manual methods to control the weeds in the crop. Due to shortage of manual labour for attending the timely weed control operations, yieldsreduced to a greater extent. In view of the above, this study was taken up to suggest the suitable weed management practice in rajmash crop in order to enhance the crop yields with less investment.

\section{Materials and Methods}

A field experiment on "weed management in rajmash (Phaseolus vulgaris L.)" was conducted during rabi 2014 and 2015 at Regional Agricultural Research Station, Chintapalli, Visakhapatnam district of Acharya N.G. Ranga Agricultural University. The experimental site was sandy clay loam in texture, low in organic carbon (0.44), available nitrogen $\left(217 \mathrm{~kg} \mathrm{ha}^{-1}\right)$, medium in available phosphorus (18.5 $\left.\mathrm{kg} \mathrm{ha}^{-1}\right)$ and high in available potassium (393 kg ha $\mathrm{kg}^{-1}$. The test variety of rajmash crop was CTPL Red, which was a native variety of Eastern Ghats of Andhra Pradesh. It is suitable for rabi season, with growth duration of 90-95 days and has an yield potential of 12-14 $\mathrm{q} \mathrm{ha}^{-1}$. The experiment consists of twelve treatments with different combinations viz., $\quad \mathrm{T}_{1}$-Pre emergence application of Pendimethalin @ $0.75 \mathrm{~kg} / \mathrm{ha}$.(1 litre/ac), $\mathrm{T}_{2}$ - Pendimethalin @ $0.75 \mathrm{~kg} / \mathrm{ha}$.(1 litre/ac) as pre emergence + Hand weeding at 30 DAS, T 3 - Pendimethalin @ 0.75 kg/ha.(1 litre/ac) as pre emergence + Imazythapyr @63 gm ai/ha $(250 \mathrm{ml} / \mathrm{ac})$ as post emergence application at $30 \mathrm{DAS}, \mathrm{T}_{4}$ - Pre emergence application of Pendimethalin @ 0.75 kg/ha.(1 litre/ac) + Post emergence of Quizalofop, $\mathrm{T}_{5}$ Pre-E of Pendimethalin @ 0.75 kg/ha.(1 litre/ac) + Post-E of Propaquizafop @ $63 \mathrm{~g}$ ai/ha (250 $\mathrm{ml} / \mathrm{ac}), \mathrm{T}_{6}$ - Pre-E application of Alachlor @ $5.0 \mathrm{ml} / \mathrm{lt}, \mathrm{T}_{7}-$ Alachlor as Pre-E + hand weeding at $30 \mathrm{DAS}, \mathrm{T}_{8}-$ Alachlor + Imazythapyr @63 gm ai/ha (250 ml /ac) at 30 DAS, $\mathrm{T}_{9}-$ Alachlor + Quizalofop at $30 \mathrm{DAS}$, $\mathrm{T}_{10}-$ Pre Emergence application of Alachlor + Post emergence application of Propaquizafop @ $63 \mathrm{~g}$ ai/ha $(250 \mathrm{ml} / \mathrm{ac})$ at $30 \mathrm{DAS}, \mathrm{T}_{11}-$ hand weeding at $30 \mathrm{DAS}$ and $\mathrm{T}_{12}-$ Controling randomized block design with three replications.

The recommended dose of 100-60-20 Kg N-P$\mathrm{K} \mathrm{ha}^{-1}$ was applied through urea, single super phosphate and muriate of potash, respectively. Entire $\mathrm{P}_{2} \mathrm{O}_{5}$ and $\mathrm{K}_{2} \mathrm{O}$ was applied basally to all the treatments. Nitrogen was applied in two splits doses of $50 \%$ basal and $50 \%$ at flowering stage. The experimental data collected were statistically analysed by following randomised block design.

\section{Results and Discussion}

\section{Yield attributes}

The yield attributes viz., number of pods per plant and number of seeds per pod of rajmash were significantly influenced by different weed management practices (Table 1). Among the different weed management practices, application of pendimethalin @ $0.75 \mathrm{~kg}$ $\mathrm{ha}^{-1}\left(1.0\right.$ litreac $\left.^{-1}\right)$ as pre-emergence+ hand weeding at 30 DAS $\left(\mathrm{T}_{2}\right)$ has recorded significantly higher number of pods per plant (14.8) and number of seeds per pod (6.8) of rajmash crop. This treatment was on a par with pendimethalin @ $0.75 \mathrm{kgha}^{-1}$ (1.0 litreac $\left.^{-1}\right)$ as pre emergence application followed byimazythapyr @63 $\mathrm{g} \mathrm{aiha}^{-1}$ (250 mlac $\left.^{-1}\right)$ as post emergence application at 30 DAS $\left(T_{3}\right)$ and hand weeding at $30 \operatorname{DAS}\left(T_{11}\right)$ 
with respect to number of pods per plant and number seed per pod i.e., 12.4 and 6.5 and 12.0 and 6.2 , respectively. The next best treatment in producing the number of pods per plant and number of seeds per pod was pre emergence application of alachlor @ $5.0 \mathrm{ml} / \mathrm{lt}$ + Imazythapyr @63 g ai/ha (250 ml /ac) at 30 DAS as post emergence application with 11.8 and 5.8, respectively. Significatly lower number of number of pods per plant and number of seeds per pod were recorded with control plot $\left(\mathrm{T}_{12}\right)$. These results of highest yield attributes with post emergence application of imazythapyr were also reported by Goud and Dikey (2016).

\section{Yield and benefit cost ratio}

Pre-emergence application of pendimethalin @ $0.75 \mathrm{kgha}^{-1}\left(1.0\right.$ litreac $\left.{ }^{-1}\right)+$ hand weeding at 30 DAS $\left(T_{2}\right)$ has produced significantly higher yield (1240.6 kg ha ${ }^{-1}$ ) of rajmash crop with benefit cost ratio of 2.30. This treatment was on a par with pendimethalin application @ $0.75 \mathrm{~kg} / \mathrm{ha}$.(1 litre/ac) as pre emergence + imazythapyr @63 gm ai/ha $(250 \mathrm{ml} / \mathrm{ac})$ as post emergence application at 30 DAS (1136.5 $\left.\mathrm{kg} \mathrm{ha}^{-1}\right)$, hand weeding at 30 DAS $(1124.0 \mathrm{~kg}$ $\mathrm{ha}^{-1}$ ) and application of alachlor as pre emergence followed by post emergence application ofimazythapyr @63 gm ai/ha (250 $\mathrm{ml} / \mathrm{ac})$ at $30 \mathrm{DAS}\left(1086.3 \mathrm{~kg} \mathrm{ha}^{-1}\right)$. Higher yields in $T_{2}, T_{3}$ and $T_{11}$ could be due to less weed intensity and higher weed control efficiency which lead to better assimilation of nutrients by the crop. The benefit cost ratio of $\mathrm{T}_{3}, \mathrm{~T}_{11}$ and $\mathrm{T}_{8}$ were $3.20,2.20$ and 2.0, respectively. The higher benefit cost ratio in $\mathrm{T}_{3}$ treatment was due to usage of post and pre emergence chemicals having no manual weeding and higher yields. These results are in similar lines with the findings of Srivastava $e t$ al., (2013). Obviously, lower yields and less B: C ratio were obtained in control treatment. Similar trend of results were reported by Goud and Dikey (2016) and Patel et al., (2017).

Table.1 Effect of weed management practices on yield attributes, yield and B: $\mathrm{C}$ ratio in rajmash crop

\begin{tabular}{|c|c|c|c|c|}
\hline Treatments & $\begin{array}{c}\text { No. of Pods / } \\
\text { Plant }\end{array}$ & $\begin{array}{c}\text { No. of Seeds / } \\
\text { Pod }\end{array}$ & Yield $\left(\mathbf{k g h a}^{-\mathbf{1}}\right)$ & B:C ratio \\
\hline $\mathbf{T}_{\mathbf{1}}$ & 6.8 & 5.4 & 784.3 & 1.70 \\
\hline $\mathbf{T}_{\mathbf{2}}$ & 14.8 & 6.8 & 1240.6 & 2.30 \\
\hline $\mathbf{T}_{\mathbf{3}}$ & 12.4 & 6.5 & 1136.5 & 3.20 \\
\hline $\mathbf{T}_{\mathbf{4}}$ & 8.8 & 5.6 & 896.7 & 1.60 \\
\hline $\mathbf{T}_{\mathbf{5}}$ & 8.4 & 5.4 & 876.0 & 1.54 \\
\hline $\mathbf{T}_{\mathbf{6}}$ & 6.3 & 5.3 & 768.4 & 1.26 \\
\hline $\mathbf{T}_{\mathbf{7}}$ & 10.4 & 5.4 & 986.6 & 1.25 \\
\hline $\mathbf{T}_{\mathbf{8}}$ & 11.8 & 5.8 & 1086.3 & 2.0 \\
\hline $\mathbf{T}_{\mathbf{9}}$ & 7.0 & 5.3 & 810.8 & 1.48 \\
\hline $\mathbf{T}_{\mathbf{1 0}}$ & 7.4 & 5.2 & 843.4 & 1.50 \\
\hline $\mathbf{T}_{\mathbf{1 1}}$ & 12.0 & 6.2 & 1124.0 & 2.20 \\
\hline $\mathbf{T}_{\mathbf{1 2}}$ & 5.2 & 5.1 & 487.5 & 0.67 \\
\hline $\mathbf{S E m} \mathbf{m}$ & 2.5 & 0.46 & 112.0 & 0.63 \\
\hline $\mathbf{C D}(\mathbf{P}=\mathbf{0 . 0 5})$ & 6.1 & 1.30 & 296.8 & 1.54 \\
\hline
\end{tabular}


Table.2 Effect of different weed management practices on weed drymatter $\left(\mathrm{g} / \mathrm{m}^{2}\right)$ and weed control efficiency (\%) in rajmash crop

\begin{tabular}{|c|c|c|c|c|}
\hline Treatments & \multicolumn{2}{|c|}{ Weed Dry matter $\left(\mathbf{g} / \mathbf{m}^{\mathbf{2}}\right)$} & \multicolumn{2}{c|}{$\begin{array}{c}\text { Weed control Efficiency } \\
\text { (WCE\%) }\end{array}$} \\
\hline & 45 DAS & At harvest & 45 DAS & At harvest \\
\hline $\mathbf{T}_{\mathbf{1}}$ & 110.0 & 155.4 & 27.2 & 29.5 \\
\hline $\mathbf{T}_{\mathbf{2}}$ & 80.5 & 125.0 & 73.9 & 61.0 \\
\hline $\mathbf{T}_{\mathbf{3}}$ & 85.2 & 134.3 & 64.3 & 49.8 \\
\hline $\mathbf{T 4}$ & 98.4 & 150.2 & 42.2 & 34.0 \\
\hline $\mathbf{T}_{\mathbf{5}}$ & 102.0 & 152.6 & 37.2 & 31.9 \\
\hline $\mathbf{T}_{\mathbf{6}}$ & 114.0 & 163.0 & 22.8 & 23.4 \\
\hline $\mathbf{T}_{\mathbf{7}}$ & 89.0 & 140.0 & 57.3 & 43.7 \\
\hline $\mathbf{T}_{\mathbf{8}}$ & 87.0 & 134.5 & 60.9 & 49.6 \\
\hline $\mathbf{T}_{\mathbf{9}}$ & 106.0 & 152.0 & 32.0 & 32.4 \\
\hline $\mathbf{T}_{\mathbf{1 0}}$ & 105.0 & 150.4 & 33.3 & 33.8 \\
\hline $\mathbf{T}_{\mathbf{1 1}}$ & 86.3 & 136.0 & 62.2 & 48.0 \\
\hline $\mathbf{T}_{\mathbf{1 2}}$ & 140.0 & 201.3 & - & - \\
\hline $\mathbf{S E m \pm}$ & 7.5 & 14.3 & 14.0 & 7.0 \\
\hline $\mathbf{C D}(\mathbf{P}=\mathbf{0 . 0 5}$ & 20.0 & 38.4 & 37.3 & 18.6 \\
\hline
\end{tabular}

\section{Weed Drymatter and Weed Control Efficiency}

Weed flora in experimental plots consists of grasses like Cynodondactylon; sedges like Cyperus rotundus and broad-leaved weeds like Celosia argentea, Physalis minima, Eclipta alba, Abutilon indicum, Amaranthus spinosus, Centella asiatica, Chrozophora rottleri, Phyllanthus niruri in rajmash field.

Weed dry matter production and weed control efficiency were significantly influenced by the different weed management practices (Table 2) in rajmash crop. Significantly less weed drymatter and high weed control efficiency (\%) at 45 DAS $\left(80.5 \mathrm{~g} \mathrm{~m}^{-2}\right.$ and $73.9 \%)$ and at harvest $\left(125.0 \mathrm{~g} \mathrm{~m}^{-2}\right.$ and $61.0 \%)$ were recorded in the plots $\left(\mathrm{T}_{2}\right)$ applied with pendimethalin @ $0.75 \mathrm{kgha}^{-1}$ $\left(1.01 \mathrm{ltac}^{-1}\right)$ as pre-emergence application + hand weeding at 30 DAS. The treatment $\mathrm{T}_{2}$ was on a par with the application of pendimethalin application @ $0.75 \mathrm{~kg} / \mathrm{ha}$ (1 litre/ac) as pre emergence + imazythapyr @63 $\mathrm{gm} \mathrm{ai} / \mathrm{ha}(250 \mathrm{ml} / \mathrm{ac})$ as post emergence at 30 DAS (64.3 $\mathrm{g} \mathrm{m}^{-2}$ and $\left.49.8 \%\right)$, hand weeding at 30 DAS $\left(62.2 \mathrm{~g} \mathrm{~m}^{-2}\right.$ and $\left.48.0 \%\right)$ and application of alachlor as pre emergence followed by post emergence application of Imazythapyr @63 gm ai/ha (250 ml /ac) at 30 DAS (60.9 $\mathrm{g} \mathrm{m}^{-2}$ and $\left.49.6 \%\right)$. The higher dry matter production of weeds was produced in weedy check plot.

Rana et al., (2004) reported the minimum weed number and dry matter accumulation were recorded with the application of pendimethalin $0.9 \mathrm{~kg}+$ alachlor $0.75 \mathrm{~kg}$ $\mathrm{ha}^{-1}$ and resulted in weed control efficiency of $71.7 \%$ as compared to weedy check. These results are in conformity with the findings of Meena et al., (2011) and Nandan et al., (2011). Similar results of hand weeding twice at 20 and 40 days after sowing followed by pre emergence application of pendimethalin $30 \mathrm{EC}+$ imazethapyr $2 \mathrm{EC}$ at $1.0 \mathrm{~kg} / \mathrm{ha}$ recorded lesser weed dry weight at 60 days 
and higher weed control efficiency reported by Chandrakar et al., 2014.

Based on the results it can be concluded that pre emergence application of pendimethalin @ $0.75 \mathrm{~kg} / \mathrm{ha}(1.0 \mathrm{lt} / \mathrm{ac})$ followed by one hand weeding at 30 DAS or pendimethalin @ 0.75 $\mathrm{kg} / \mathrm{ha}(1.0 \mathrm{lt} / \mathrm{ac})$ as pre emergence + post emergence application of imazythapyr @ $63 \mathrm{~g}$ ai/ha $(250 \mathrm{~m} / \mathrm{ac})$ at 30 DAS can control maximum weed flora efficiently in rajmash crop for obtaining the higher yield.

\section{References}

Chandrakar, D.K, Chandrakar Kusum, Singh A.P, Nair S.K. and Nanda, H.C. 2014. Efficacy of different herbicides on weed dynamics and performance of rajmash (Phaseolus vulgaris L.). Journal of Food Legumes. 27(4): 344-346.

Goud, V.V. and Dikey, H.S. 2016. Postemergence herbicides for weed management in French bean. Indian Journal of Weed Science. 48 (2): 191194.

Meena, D.S, Baldev Ram, Chaman Jadon and Tetarwal, J.P. 2011. Efficacy of imazethapyr on weed management in soybean. Indian Journal of Weed Science. 43: 169-171.

Nandan, B, Sharma, B.C, Anil Kumar and Vikas Sharma. 2011. Efficacy of pre and post emergence herbicides of weed flora of urdbean under rainfed subtropical Shivalik foothills of Jammu
\& Kashmir. Indian Journal of Weed Science. 43: 172-174.

Panotra, S, Singh, O.P. and Kumar, A. 2012. Effect of chemical and mechanical weed management on yield of French bean-sorghum cropping system. Indian Journal of Weed Science. 44(3): 163166.

Patel, R.I, Piyush Kumar Saras, Patel, C.K, Neha V. Patel and Rabari, K.V. 2017. Effect of Integrated Crop Management Practices on Growth and Yield of Rajmash (Phaseolus Vulgaris L.). International Journal of Science, Environment and Technology. 6 (4): 2437-2444.

Rana, M. C, Sharma, G.D, Sharma Akhilesh and Rana, S.S.2004. Effect of Weed Management and Fertility Levels on Rajmash (Phaseolus vulgaris) and Associated Weeds under Dry Temperate High Hills in Himachal Pradesh. Indian Journal of Weed Science. 36 (3\&4): 227-230.

Singh, V.K., Singh, G.R and Dubey, S.K. 2014. Effect of agronomic practices on growth, dry matter and yield of rajmash (Phaseolus vulgaris L.). African Journal of Agricultural Research. 9(51): 3711-3719.

Srivastava, A.K, Anuj Kumar, Yadav, D.D and Vishram Singh. 2013. Influence of weed management practices on weed, crop yield and economics of rajmash (Phaseolus vulgaris L.). Plant Archives. 13: 235-238.

\section{How to cite this article:}

Sekhar, D., L. Suryanarayana and Tejeswara Rao, K. 2018. Effect of Weed Management Practices in Rajmash (Phaseolus vulgaris L.). Int.J.Curr.Microbiol.App.Sci. 7(09): 124-128. doi: https://doi.org/10.20546/ijcmas.2018.709.016 